\title{
Karakteristik Sifat Fisik dan Daya Dukung Tanah Endapan Aluvium Daerah Caruban
}

\author{
Wahyu Budi Kusuma \\ PPSDM Migas
}

\begin{abstract}
Abstrak
Pelaksanaan pembangunan infrastruktur memerlukan berbagai informasi geologi yang salah satunya adalah informasi geologi teknik. Tanah lunak merupakan salah satu jenis tanah yang mempunyai karakteristik keteknikan tertentu yang kerap menimbulkan permasalahan pada bangunan infrastuktur diatasnya. Penelitian ini bertujuan untuk mengidentifikasi karakteristik sifat fisik dan menentukan daya dukung tanah sebagai dasar pembangunan infrastruktur. Karakteristik sifat fisik tanah diidentifikasi dari hasil uji laboratorium mekanika tanah sedangkan daya dukung tanah dihitung berdasarkan data uji penetrasi sondir. Dari hasil analisis dapat diketahui bahwa tanah tidak dalam kondisi jenuh, mudah menyerap air dan potesi perubahan komposisi kandungan dalam pori cukup tinggi. Daya dukung tanah termasuk dalam kategori rendah hingga sedang..
\end{abstract}

Kata kunci: Sifat fisik, mekanika tanah, sondir, daya dukung

\section{Abstract}

The implementation of infrastructure development requires a variety of geological information, one of which is technical geological information. Soft soil is one type of soil that has certain engineering characteristics that often cause problems in the infrastructure above. This study aims to identify the characteristics of physical properties and determine the bearing capacity of the soil as the basis for infrastructure development. The characteristics physical properties of soil were identified from the results of soil mechanics laboratory tests while soil bearing capacity was calculated based on cone penetration test data. As the results, the soil is not in a saturated condition, easily absorbs water and the potential changes in composition of the content in the pore are quite high. The bearing capacity of the soil is included in the low to moderate category.

Keywords: Physical properties, soil mechanics, cone penetration test, bearing capacity

\section{Pendahuluan}

Pelaksanaan pembangunan infrastruktur memerlukan berbagai informasi geologi yang salah satunya adalah informasi geologi teknik. Ketersediaan data dan informasi geologi teknik diperlukan untuk mendukung tercapainya pembangunan infrastruktur yang aman. Infrastruktur yang sudah ada atau sedang dibangun juga memerlukan pemantauan dan pemeliharaan, sehingga umur pakai infrastruktur yang ada dapat sesuai dengan perhitungan yang sudah dibuat pada waktu perencanaan.

Upaya pembangunan Kabupaten Madiun dihadapkan pada berbagai kendala yang erat kaitannya dengan kondisi geologi seperti dae- 
rah rawan banjir, kondisi jalan bergelombang dan bahaya gerakan tanah sehingga diperlukan informasi geologi yang baik sebagai dasar pengembangan daerah.

Tanah lunak merupakan salah satu jenis tanah yang mempunyai karakteristik keteknikan tertentu yang kerap menimbulkan permasalahan pada bangunan infrastuktur diatasnya. Salah satu masalah yang sering muncul pada infrastruktur yang dibangun di atas tanah lunak adalah amblesan.

Dalam perencanaan pembangunan sarana dan prasarana perlu dicermati keberadaan tanah lunak karena memerlukan penanganan khusus. Semakin rinci kita mengenal tanah lunak diharapkan semakin mudah kita melakukan rekayasa untuk mengatasi permasalahan yang mungkin timbul.

Data dan informasi tanah lunak ini seyogyanya dimanfaatkan untuk memperkecil dampak keberadaan tanah lunak terhadap infrastruktur, sehingga dapat mengurangi permasalahan yang akan timbul baik dalam perencanaan, pelaksanaan pembangunan maupun dalam perawatan setelah dibangunnya infrastruktur tersebut.

Penelitian kali ini difokuskan pada analisa sifat fisik untuk menentukan daya dukung tanah sebagai dasar pembangunan infrastruktur. Tujuan dari penelitian ini adalah:

- Identifikasi karakteristik sifat fisik tanah

- Menghitung daya dukung tanah untuk berbagai jenis pondasi.

Lokasi penelitian secara administratif berada di provinsi Jawa Timur meliputi 2 (dua) Kabupaten yaitu Kabupaten Madiun dan Kabupaten Ngawi, seperti terlihat pada gambar 1.1. Batas koordinat daerah penelitian adalah $106032^{\prime} 00$ " - 111040 ' 00" BT dan 70 26'00" - $7033^{\prime} 00$ " LS.

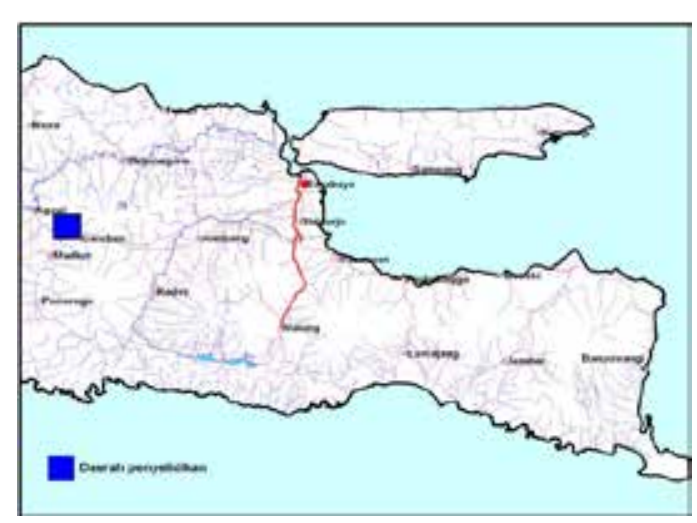

Gambar 1. Daerah Penelitian

\section{Tinjauan Pustaka}

Berdasarkan klasifikasi fisiografi Jawa (Bemmelen, 1949), Daerah penelitian terletak pada Sub Zona Ngawi yang merupakan rangkaian pegunungan di Zona Solo /Zona Depresi Tengah yang tersusun oleh endapan Kuarter dan ditempati oleh deretan gunungapi.

Daerah penelitian merupakan bagian dari sistem geomorfologi Kompleks Gunung Wilis - Gunung Liman. Berdasarkan Peta Morfologi Daerah Madiun dan Sekitarnya (Wawan H., dan Ediwan S., 2010) serta Peta Geologi Lembar Madiun, Jawa, skala 1:100.000 (U. Hartono, dkk., 1992) daerah penelitian merupakan satuan morfologi pedataran yang disusun oleh endapan Aluvium (Qal) berupa material hasil aktifitas gunungapi. Tidak dijumpai adanya struktur geologi yang mempengaruhi pola morfologi di daerah ini.

Stratigrafi di daerah pemetaan menurut Hartono, dkk., (1992) masuk dalam Formasi Notopuro dan Aluvium. Formasi Notopuro terletak tidak selaras di atas Formasi Kabuh (Qpk). Litologi penyusunnya terdiri dari tuf berselingan dengan batupasir tufaan dan konglomerat volkanik. Makin ke atas, sisipan batupasir tufaan makin banyak. Juga terdapat sisipan atau lensa - lensa breksi volkanik dengan fragmen kerakal, terdiri dari andesit dan batuapung, yuang merupakan ciri khas Formasi Notopuro. Formasi ini pada umumnya merupakan en- 
dapan lahar yang terbentuk pada lingkungan darat, berumur Plistosen Akhir dengan ketebalan mencapai lebih dari 240 meter. Sedangkan endapan alluvium terdiri dari pasir, kerikil, lumpur dan kerakal bersifat lepas kecuali pada lumpur dan pasir halus sedikit mampat. Tanah pelapukan di permukaan di dominasi oleh lempung-lempung lanauan sedangkan di daerah aliran sungai di dominasi oleh lanau lempungan.

Berdasarkan Peta Geologi Teknik Tinjau Lembar Madiun skala 1: 100.000 (Wawan H., dan Ediwan S., 2010), Aluvium merupakan endapan hasil transport dari material hasil aktivitas gunungapi terutama aktivitas G. Wilis yang terdiri dari lempung, lanau, pasir, kerikil, kerakal dan sedikit bongkah. Litologinya bersifat lepas kecuali pada lumpur dan pasir halus sedikit mampat.

Menurut Wawan H., dan Ediwan S., (2010), Geologi Teknik Aluvium dipermukaan didominasi oleh lempung-lempung lanauan, coklat tua-kehitaman, plastisitas sedang-tinggi, konsistensi agak teguh-teguh, dibawahnya merupakan perselingan lanau lempungan, lanau pasiran dan pasir lanauan.

Metode analisa untuk pondasi dangkal yang umum digunakan saat ini (Fang, H.Y dan Daniels, J.L., 2006) ada 5 (lima) yaitu: Slip-Line method, Limit equilibrium method, Limit analysis method, Finite difference method, Finite element method.

Konsep daya dukung yang dicetuskan oleh Terzaghi (1943), Taylor (1948), Skempton (1951) dan Meyerhof (1955) termasuk dalam Limit equilibrium method. Di dalam pembahasan kali ini, perhitungan daya dukung tanah dilakukan berdasarkan limit equilibrium method menggunakan konsep Terzaghi (dalam Fang, H.Y dan Daniels, J.L., 2006) (Gambar 2).

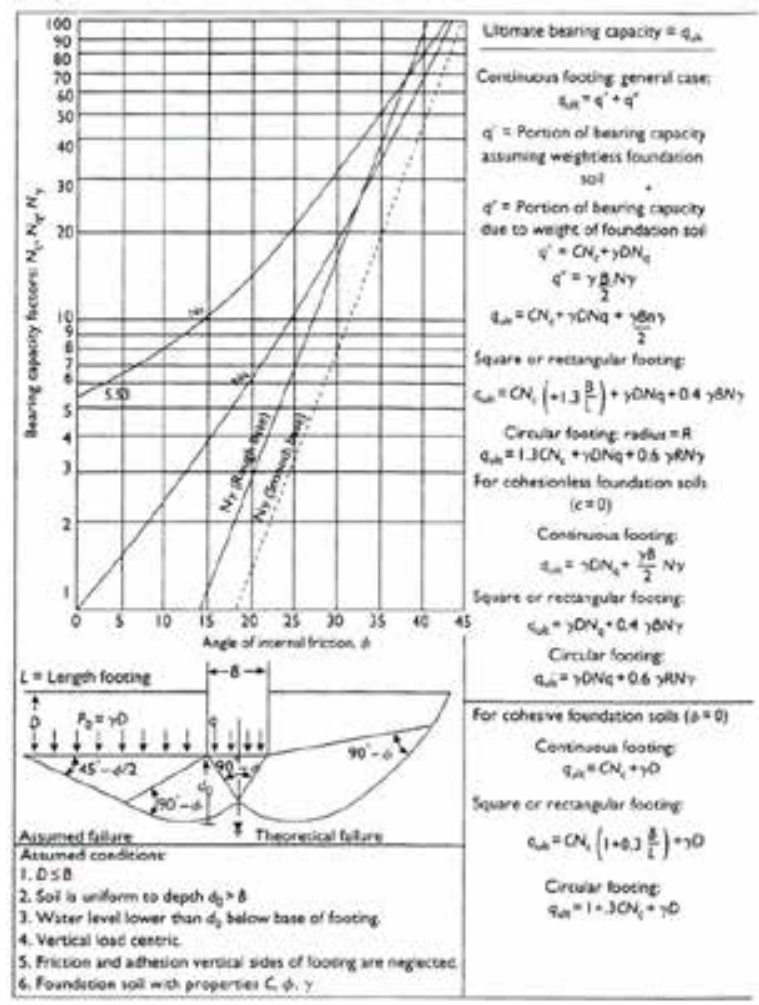

Gambar 2. Daya dukung pondasi dangkal konsep Terzaghi (dalam Fang, H.Y dan Daniels, J.L., 2006)

\section{Metode Penelitian}

Metode penelitian yang digunakan dalam penelitian ini ada 2 (dua) yaitu:

1. Metode Deskriptif

Metode deskriptif ini terdiri dari studi pustaka dan studi kasus. Studi pustaka dilakukan dengan cara mengumpulkan literatur dan mengolah data dan informasi dari berbagai literatur tersebut. Sedangkan studi kasus dilakukan untuk menggambarkan secara rinci mengenai stratigrafi dan karakteristik tanah.

2. Metode Kuantitatif

Metode ini terdiri dari analisis laboratorium untuk mendapatkan nilai sifat fisik tanah, kemudian nilai tersebut digunakan untuk mendapatkan nilai daya dukung tanah. 


\section{Hasil Penelitian dan Pembahasan}

\section{Sifat Fisik Tanah}

Berikut ini adalah beberapa sifat fisik tanah di daerah penelitian yang didasarkan pada hasil uji laboratorium mekanika tanah.

\section{1) Kadar Air dan Derajat Kejenuhan}

Tanah di daerah penelitian mempunyai nilai derajat kejenuhan cukup bervariasi pada kisaran 77 - $95 \%$ dan kadar air berkisar antara 27 - 62\% (Tabel 3.1), kondisi ini menunjukkan bahwa tanah dalam kondisi belum jenuh dan jika melihat dominasi ukuran butir berupa lempung maka salah satu kemungkinan tingginya kadar air diakibatkan oleh kemampuan mineral lempung (montmorilonite group) menyerap air. Tanah ekspansif memiliki kemampuan menyerap air yang sangat tinggi dan kecenderungan untuk mengembang ketika kadar air meningkat (El Sohby dan Rabba, 1981; Wayne et al, 1984; Chen et al, 1985; Mowafy et al, 1985; Popescu, 1986; Gens dan Alonso, 1992; Sivapullaiah, 1996 dalam Bambang P., dan Arif H., 2006). Sampel tanah diambil dalam kondisi iklim kemarau (kering) sehingga jika musim hujan memungkinkan terjadi penambahan kadar air tanah dan peningkatan derajat kejenuhan sehingga perlu penanganan yang khusus terutama pada perubahan kadar airnya jika tanah bersifat ekspansif.

Tabel 1 Nilai Kadar Air dan Derajat Kejenuhan

\begin{tabular}{|l|c|c|}
\hline \multicolumn{1}{|c|}{$\begin{array}{c}\text { Konsistensi } \\
\text { Tanah }\end{array}$} & Kadar Air & $\begin{array}{c}\text { Derajat } \\
\text { Kejenuhan }\end{array}$ \\
\hline $\begin{array}{l}\text { Sangat lunak - } \\
\text { lunak }\end{array}$ & $29,99-59,61$ & $82,93-94,88$ \\
\hline Teguh & $30,92-61,43$ & $77,36-94,47$ \\
\hline
\end{tabular}

\begin{tabular}{|l|c|c|}
\hline $\begin{array}{l}\text { Kaku - sangat } \\
\text { kaku }\end{array}$ & $27,62-44,37$ & $83,44-91,36$ \\
\hline
\end{tabular}

\section{2) Angka Pori dan Porositas}

Angka pori dari tanah di daerah penelitian umumnya $>1$ dan porositas kecenderungannya di atas $50 \%$, hal ini menunjukkan bahwa volume rongga cukup besar, lebih besar dibandingkan dengan volume padat. Dari dua parameter ini menunjukkan bahwa potensi perubahan komposisi kandungan dalam rongga (air dan udara) cukup tinggi. Berdasarkan Tabel 2, tidak terlihat korelasi secara langsung antara nilai angka pori dan porositas terhadap konsistensi tanah tetapi perubahan komposisi kandungan pori sangat berpengaruh pada kekuatan tanah di daerah penelitian.

Tabel 2 Nilai Angka Pori dan Porositas

\begin{tabular}{|c|c|c|}
\hline $\begin{array}{l}\text { Konsistensi } \\
\text { Tanah }\end{array}$ & Angka Pori & $\begin{array}{l}\text { Porosi- } \\
\text { tas }\end{array}$ \\
\hline $\begin{array}{l}\text { Sangat lunak - } \\
\text { lunak }\end{array}$ & $0,92-1,64$ & $\begin{array}{c}48,01- \\
62,06\end{array}$ \\
\hline Teguh & $0,97-1,68$ & $\begin{array}{c}49,24- \\
62,67\end{array}$ \\
\hline $\begin{array}{l}\text { Kaku - sangat } \\
\text { kaku }\end{array}$ & $0,86-1,34$ & $\begin{array}{c}46,17- \\
57,26 \\
\end{array}$ \\
\hline
\end{tabular}

\section{3) Distribusi Ukuran Butir}

Ukuran tiap-tiap butir tanah yang ada didalam tanah merupakan pembentuk testur tanah. Ukuran butir tanah secara umum dibagi menjadi dua yaitu butiran kasar (pasir, kerikil hingga kerakal) dan butiran halus (lanau dan lempung). Distribusi ukuran butir berpengaruh sangat besar dalam sistem klasifikasi tanah. Beberapa sistem klasifikasi tanah seperti AASHTO, USDA dan USCS menggunakan distribusi ukuran butir sebagai dasar klasifikasi. 


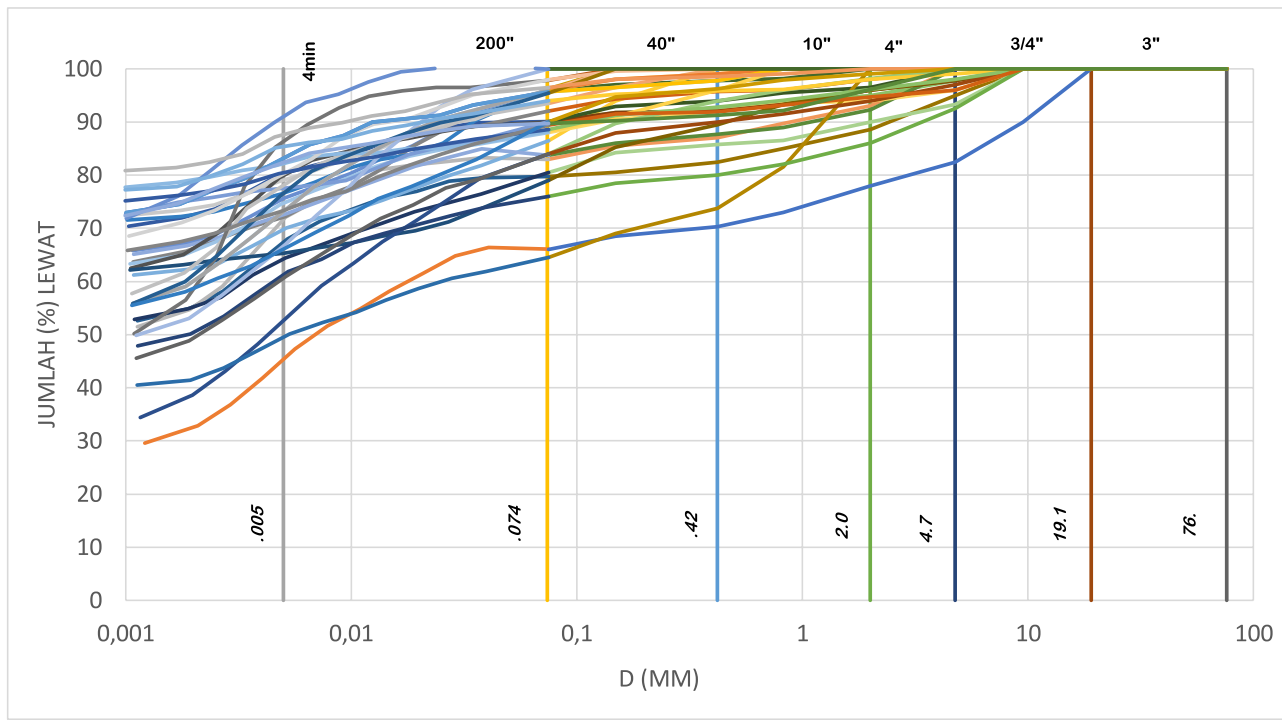

Gambar 3 Grafik Distribusi Ukuran Butir

Berdasarkan hasil analisa besar butir maka dapat dilihat bahwa di daerah penelitian di dominasi oleh tanah dengan butir berukuran lempung ( $>60 \%$ ) bercampur dengan lanau ( $\leq 23 \%$ ), pasir $(\leq 19 \%)$, dan kerikil halus ( $\leq$ 7\%) (Gambar 3). Pola distribusi butir yang berbeda ditunjukkan pada TS 01 (biru), TS 18 (ungu), TS 20 (oranye) dan TS 21 (merah). TS 01, TS 18 dan TS 20 mengandung lempung kurang dari $60 \%$ tetapi masih tetap dominan (>45\%) dibanding dengan ukuran butir yang lain. Kandungan lanau pada TS 18 dan TS 21 cukup besar ( $>30 \%)$, sedangkan kandungan pasir pada TS 20 mencapai 35\% dan kerikil halus pada TS 01 mencapai 18\%.

\section{4) Batas Indeks Tanah}

\section{a. Batas Atterberg}

Tanah yang batas cairnya tinggi biasanya mempunyai sifat teknik yang buruk yaitu kekuatannya rendah, kompresibilitasnya tinggi sehingga sulit dalam hal pemadatanya. Batasbatas atterberg yang dapat diketahui dalam penelitian ini adalah batas cair (LL), batas plastis (PL), indeks plastis (IP) dan batas susut (SL).
Apabila nilai Indeks Plastisitas tinggi, maka tanah banyak mengandung butiran lempung. Indeks plastis dapat digunakan untuk menghitung potensi pengembangan tanah. Nilai Indeks Plastis tanah di daerah penelitian cukup tinggi ( $>60 \%)$ menunjukkan adanya potensi sifat mengembang yang tinggi.

Kontak langsung tanah dengan atmosfer pada musim kemarau (waktu penelitian) merupakan penyebab hilangnya kadar air pada tanah hingga tanah di permukaan mengalami penyusutan tetapi pengaruh atmosfer hanya terjadi di permukaan. Contoh tanah tak terganggu diambil pada kedalaman rata-rata 1,00 m dan hasil ujinya menunjukkan kadar airnya relatif cukup tinggi (27\% - 62\% lihat Tabel 1) hal ini menunjukkan pengaruh atmosfer tidak terlalu besar. Kondisi alami tanah dapat dipertahankan jika kontak tanah dengan atmosfer dapat dihindari atau dipersingkat waktunya. 


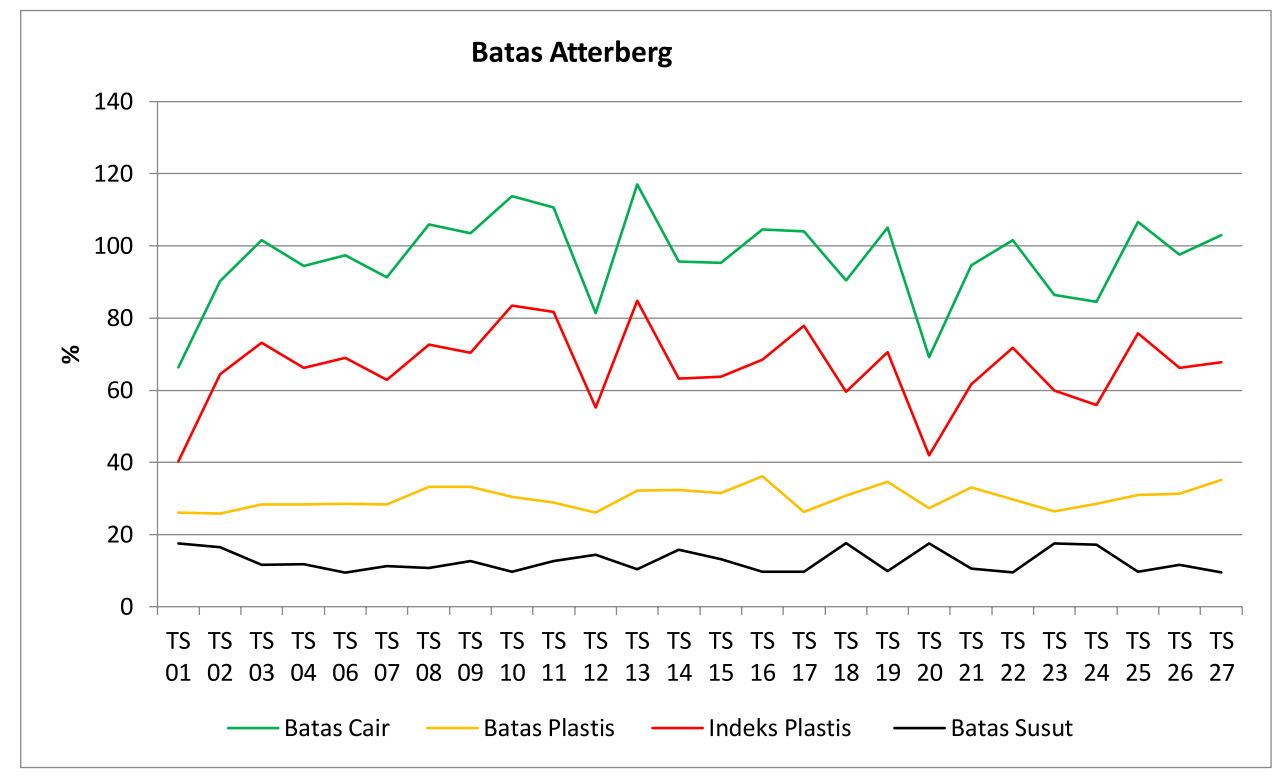

Gambar 4 Batas Atterberg Tanah di Daerah Penelitian

Berdasarkan nilai kadar air dan batas susut terlihat bahwa potensi penyusutan volume sangat rendah (Gambar 5). Potensi penyusutan volume tinggi jika kadar air berada di bawah batas susut.

Kenampakan di lapangan pada tanah dipermukaan menunjukkan kondisi penyusutan volume tanah yang cukup besar. Penyusutan volume tanah yang cukup besar dipermukaan menyebabkan tanah mengalami rekah-rekah dengan lebar rekahan hingga $15 \mathrm{~cm}$ dan kedalaman $30 \mathrm{~cm}$.

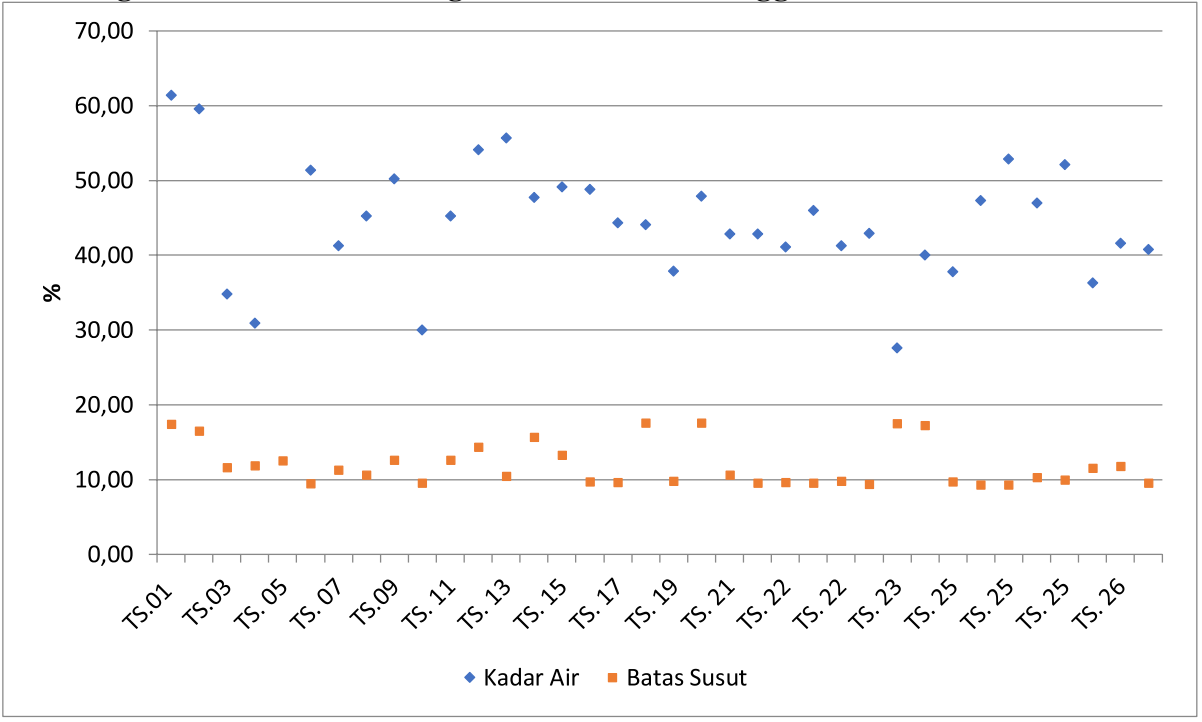

Gambar 5 Hubungan Kadar Air dan Batas Susut

\section{b. Indeks Kompresibilitas}

Indeks Kompresibilitas $\left(\mathrm{C}_{\mathrm{c}}\right)$ tanah adalah perubahan rongga antar butir (void ratio) dari masa tanah akibat pertambahan tekanan efektif secara vertikal. Umumnya nilai indeks kompresibilitas ini dihitung menggunakan Oedometer test. Hasil dari perhitungan ini memperlihatkan nilai indeks kompresibilitas tanah di daerah penelitian yang berupa tanah lempung sangat lunak-lunak berkisar antara 
$0,1863-0,3774$. Untuk lempung yang teguh berkisar antara 0,1474 - 0,5847 dan untuk lempung kaku-sangat kaku berkisar antara 0,1168 - 0,2836 (Gambar 6).

Hasil dari perhitungan empiris menggunakan persamaan $\mathrm{Cc}=0.85\left(\mathrm{~W}_{\mathrm{n}} / 100\right)^{1,5}$ diperoleh nilai indeks kompresibilitas tanah di daerah penelitian yang berupa tanah lempung lunak berkisar antara 0,1396-0,3912. Untuk lempung yang teguh berkisar antara 0,1474 0,5847 dan untuk lempung kaku-sangat kaku berkisar antara 0,1168-0,2836 (Gambar 8).

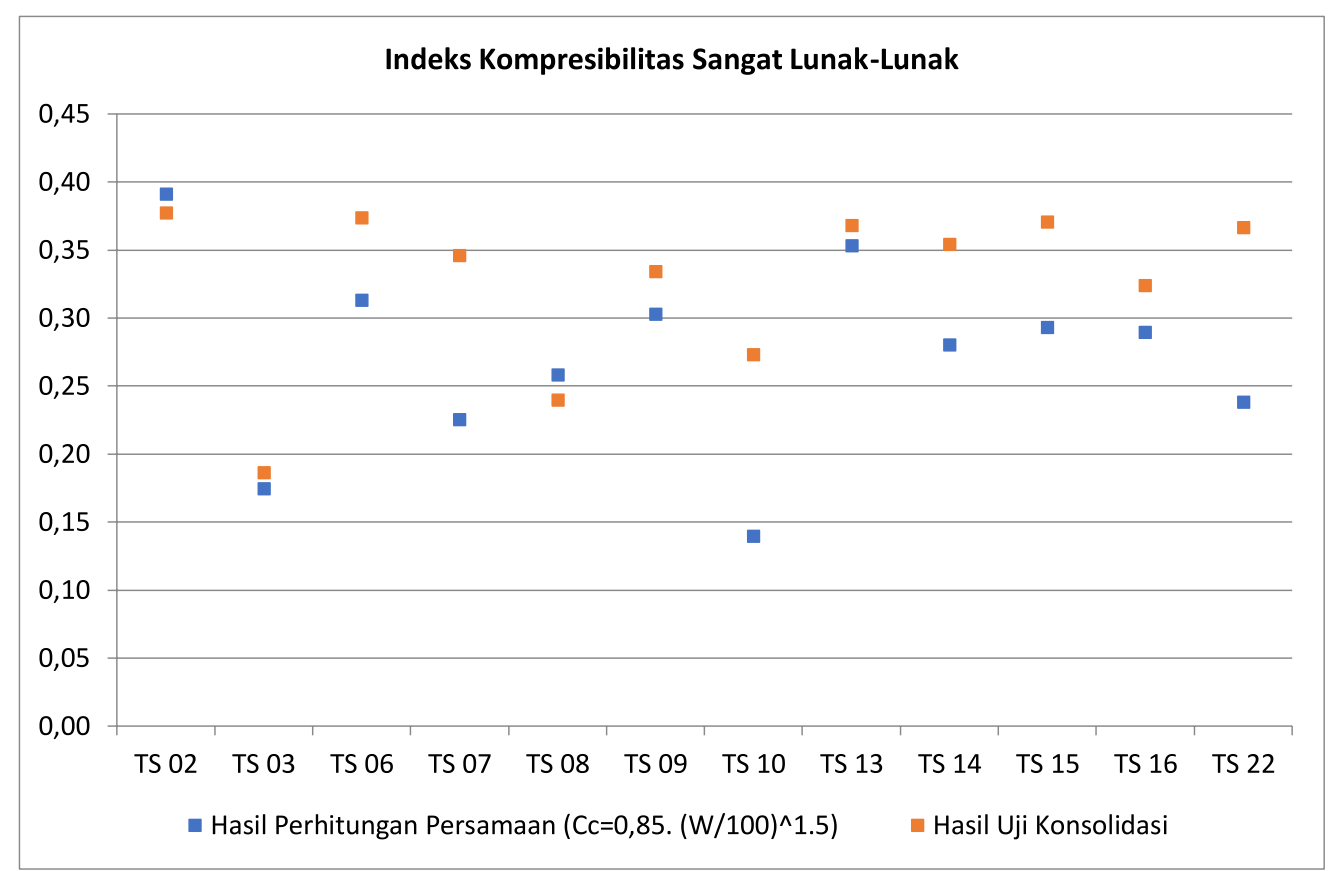

Gambar 6 Grafik Nilai Indeks Kompresibilitas Untuk Jenis Tanah Sangat Lunak-Lunak

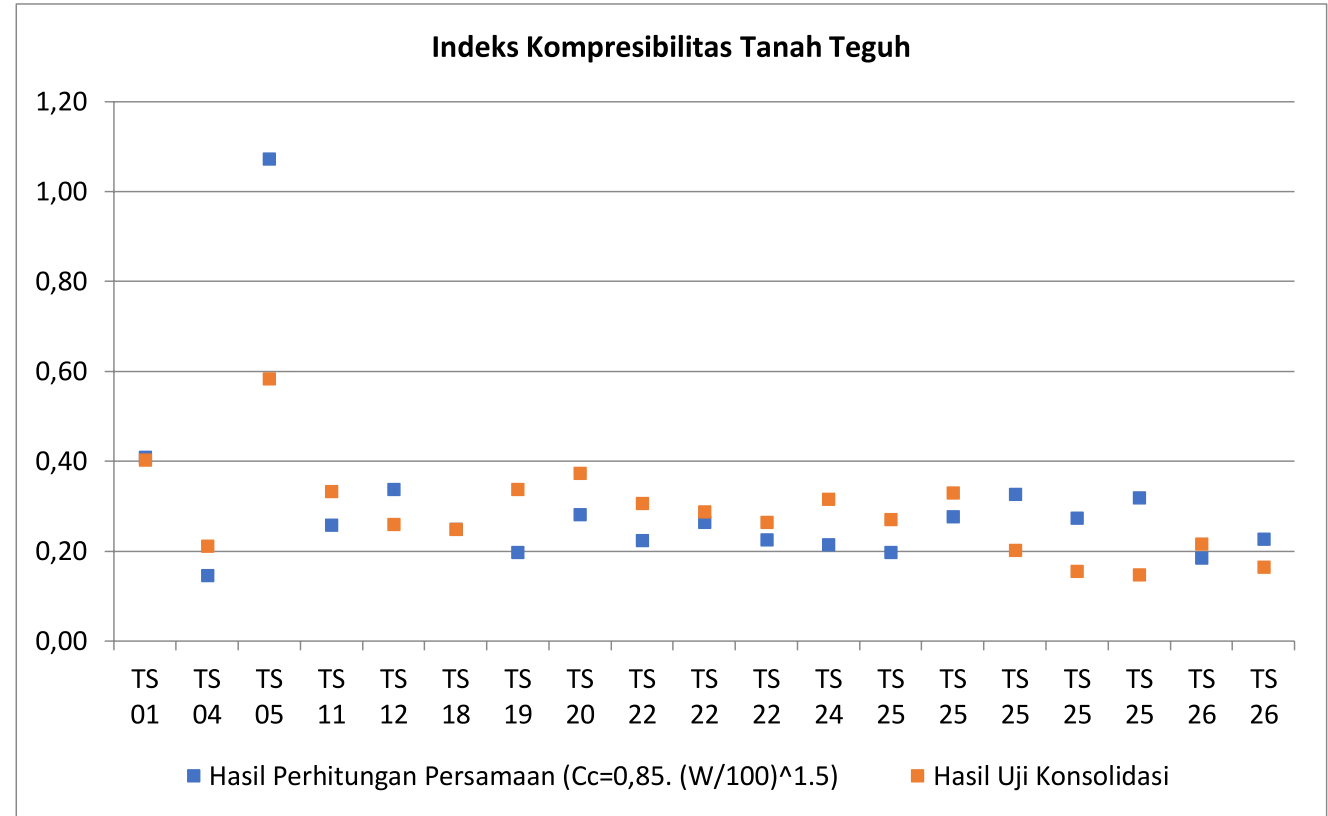

Gambar 7 Grafik Nilai Indeks Kompresibilitas Untuk Jenis Tanah Teguh 


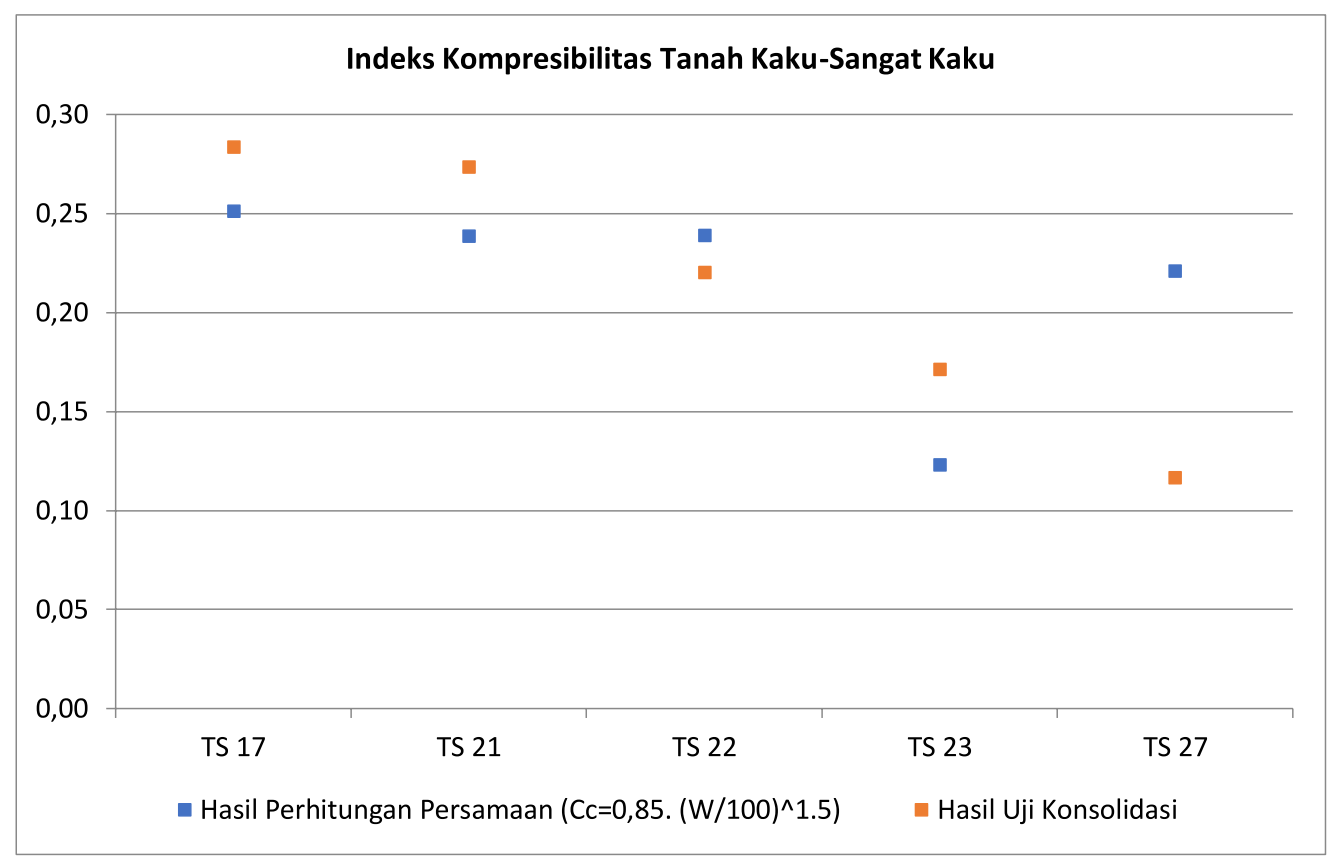

Gambar 8 Grafik Nilai Indeks Kompresibilitas Untuk Jenis Tanah Kaku-Sangat Kaku

\section{c. Indeks Pengembangan (Swell Index)}

Indeks Pengembangan berkaitan erat dengan potensi pengembangan tanah. Jika indeks pengembangan tanah tinggi maka potensi pengembangan tanah juga tinggi. Uji untuk mengetahui nilai indeks pengembangan tanah adalah dengan konsolidasi. Indeks pengembangan berkaitan erat dengan potensi perubahan volume akibat penambahan dan pengurangan kadar air dalam tanah. Berikut ini adalah nilai indeks pengembangan hasil uji konsolidasi yang dilakukan pada tanah dengan jenis konsistensi yang berbeda (Tabel 3). Tidak ada perbedaan yang berarti dari nilai kisaran swell index untuk jenis konsistensi yang berbeda.

Tabel 3. Nilai swell index pada jenis konsistensi tanah yang berbeda

\begin{tabular}{|l|c|}
\hline \multicolumn{1}{|c|}{ Konsistensi Tanah } & Swell Index \\
\hline Sangat lunak - lunak & $0.038-0.087$ \\
\hline Teguh & $0.041-0.078$ \\
\hline Kaku - sangat kaku & -0.078 \\
\hline
\end{tabular}

\section{Kohesi dan Sudut Geser Dalam}

Kekuatan geser tanah diperlukan untuk menghitung daya dukung tanah (bearing capacity), tegangan tanah terhadap dinding penahan (earth pressure) dan kestabilan lereng. Kekuatan geser tanah terdiri dari dua parameter yaitu :

1. Bagian yang bersifat kohesif

2. Bagian yang mempunyai sifat gesekan / frictional yang sebanding dengan tegangan efektif $(\sigma)$ yang bekerja pada bidang geser.

Kekuatan geser dalam mempunyai variabel kohesi dan sudut geser dalam. Kohesi merupakan gaya tarik menarik antar partikel tanah. Bersama dengan sudut geser dalam, kohesi merupakan parameter kuat geser tanah yang menentukan ketahanan tanah terhadap deformasi akibat tegangan yang bekerja pada tanah dalam hal ini berupa gerakan lateral tanah. Deformasi ini terjadi akibat kombinasi keadaan kritis pada tegangan normal dan tegangan geser yang tidak sesuai dengan faktor 
aman dari yang direncanakan.

Berdasarkan uji triaxial kita dapat memperoleh nilai kohesi, dan sudut geser dalam. Nilai kohesi dan sudut geser dalam dibutuhkan untuk menentukan perilaku tanah jika terjadi perubahan kondisi fisiknya akibat dari perubahan iklim, pembebanan, pemotongan/ penggalian dan rekayasa lainnya. Perubahan perilaku tanah ini harus menjadi perhatian dalam perencanaan pembangunan infrastruktur di atasnya. Berikut ini adalah hasil uji mekanika tanah terhadap sifat mekanik tanah yang tercermin dalam nilai kohesi dan sudut geser dalam di daerah penelitian (Tabel 4).

Tabel 4 Nilai kohesi dan sudut geser dalam

\begin{tabular}{|l|c|c|}
\hline \multicolumn{1}{|c|}{$\begin{array}{c}\text { Konsistensi } \\
\text { Tanah }\end{array}$} & Kohesi & $\begin{array}{c}\text { Sudut geser } \\
\text { dalam }\end{array}$ \\
\hline $\begin{array}{l}\text { Sangat lunak - } \\
\text { lunak }\end{array}$ & $0,069-0,309$ & $4,05-10,79$ \\
\hline Teguh & $0,043-0,342$ & $2,06-10,98$ \\
\hline $\begin{array}{l}\text { Kaku - sangat } \\
\text { kaku }\end{array}$ & $0,150-0,409$ & $7,06-13,28$ \\
\hline
\end{tabular}

\section{Daya Dukung Tanah}

Daya dukung tanah mempunyai peranan yang sangat penting dalam perencanaan konstruksi bangunan. Daya dukung tanah merupakan kemampuan tanah untuk menahan beban pondasi tanpa mengalami keruntuhan. Tanah mempunyai sifat untuk meningkatkan kepadatan dan kekuatan gesernya apabila menerima tekanan. Apabila beban yang bekerja pada tanah pondasi telah melampaui daya dukung batasnya, atau dengan kata lain tegangan geser yang ditimbulkan dalam tanah pondasi telah melampaui kekuatan geser tanahnya, maka tanah tersebut mengalami keruntuhan geser.

\section{Tekanan Konus}

Salah satu metode pengukuran langsung daya dukung tanah adalah sondir. Berdasarkan SNI 2827:2008 tentang Cara Uji Penetrasi La- pangan Dengan Alat Sondir, perlu di lakukan koreksi pada data pembacaan tekanan konus terhadap dimensi konus dan piston. Persamaan untuk memperhitungkan pengaruh dari dimensi konus dan piston adalah sebagai berikut:

- Tahanan konus

$$
q_{c}=\frac{C_{w} A_{\dot{p}}}{A_{c}}
$$

dengan: $q_{c}=$ tahanan konus

$C_{w}=\begin{aligned} & \text { bacaan manometer untuk } \\ & \text { tahanan konus }\end{aligned}$

$A_{p i}=$ luas penampang piston

$A_{c}=$ luas penampang konus

- Hambatan lekat

$$
f_{s}=\frac{\left(T_{w}-C_{w}\right) A_{\dot{p}}}{A_{s}}
$$

dengan: $f_{s}=$ hambatan lekat

$$
\begin{aligned}
T_{w}= & \text { bacaan manometer untuk } \\
& \text { tahanan konus dan selubung } \\
A_{p i}= & \text { luas penampang piston } \\
A_{s}= & \text { luas penampang selubung }
\end{aligned}
$$

Kecepatan penetrasi yang disarankan pada SNI 2827:2008 berkisar antara $1 \mathrm{~cm} /$ detik sampai $2 \mathrm{~cm} /$ detik $\pm 0,5 \mathrm{~cm}$. Untuk tanah lunak, disarankan digunakan kecepatan $2 \pm$ $0,5 \mathrm{~cm} /$ detik. Data uji sondir sebaiknya dikorelasikan secara langsung di lapangan dengan data pemboran pada satu atau lebih titik penelitian. Untuk mengidentifikasi tipe tanah, setelah dilakukan korelasi dengan data bor, selanjutnya dilakukan korelasi pada grafik untuk sondir mekanik.

Pada kegiatan penelitian tanah lunak ini dilakukan uji sondir pada 25 lokasi tersebar di seluruh daerah penelitian. Hasil sondir di 25 lokasi dapat dilihat pada Gambar 9 dan Gam- 
bar 10. Bardasarkan pada data sondir dibuat sebaran tekanan konus pada kedalaman 1, 2, 5 dan 10 meter. Rentang nilai tekanan konus disesuaikan dengan rentang nilai konsistensi tanah berdasarkan Bagemann (1965).



Gambar 9. Grafik Tekanan Konus

\section{Daya Dukung Pondasi Dangkal}

Daerah penelitian di dominasi oleh jenis tanah campuran yaitu lempung mengandung lanau, pasir dan kerikil sehingga perhitungan daya dukung pondasi dangkal $(\mathrm{D} \leq \mathrm{B})$ dihitung menggunakan persamaan sebagai berikut;

- Daya dukung tanah untuk pondasi lajur

$$
q_{u l t}=c N c+\gamma D N q+\gamma \frac{B}{2} N \gamma
$$

- Daya dukung tanah untuk pondasi bujur sangkar

$$
q_{u l t}=c N c 1,3 \frac{B}{L}+\gamma D N q+0,4 \gamma B N \gamma
$$

- Daya dukung tanah untuk pondasi lingkaran

$$
q_{u l t}=1,3 c N c+\gamma D N q+0,6 \gamma R N \gamma
$$

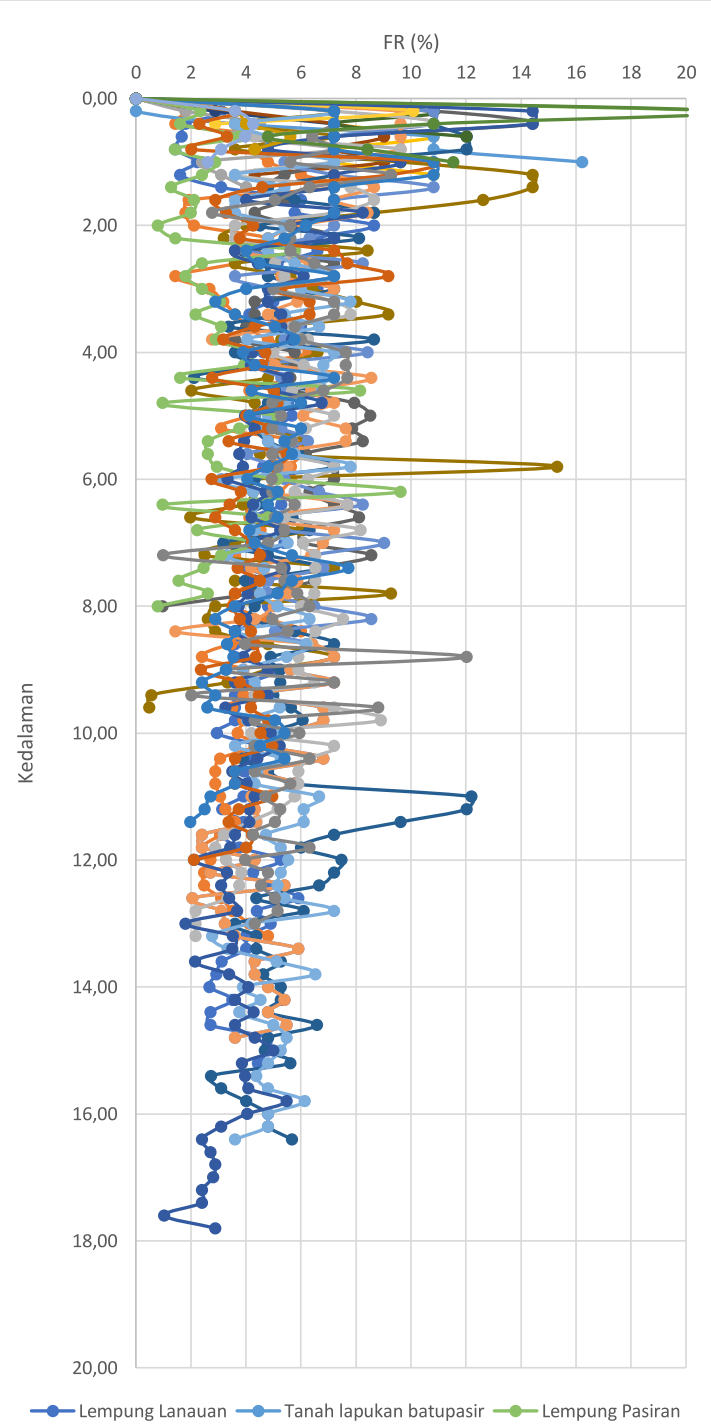

Gambar 10. Grafik Friction Ratio (FR)

Hasil perhitungan daya dukung tanah untuk pondasi dangkal dapat dilihat pada Tabel 5. Asumsi yang digunakan adalah kedalaman pondasi (D) 1,00 meter, lebar pondasi (B) 1,00 meter, panjang pondasi (L) 1,00 meter dan radius pondasi (R) 0,50 meter. 
Daya dukung fondasi dangkal untuk jenis pondasi lajur berkisar antara 1,584 hingga 13,620 ton $/ \mathrm{m}^{2}$, pondasi bujursangkar 1,846 hingga 17,179 ton $/ \mathrm{m}^{2}$ dan untuk jenis pondasi lingkaran berkisar antara 1,836 hingga 17,124 ton $/ \mathrm{m}^{2}$. Daya dukung pondasi dangkal di daerah penelitian untuk semua jenis pondasi berkisar antara rendah hingga sedang.

\section{Tabel 5. Daya Dukung Pondasi Dangkal Pada Satuan Geologi Teknik}

\begin{tabular}{|c|c|c|c|c|}
\hline $\begin{array}{c}\text { Satuan } \\
\text { Geologi } \\
\text { Teknik }\end{array}$ & $\begin{array}{l}\text { Pon- } \\
\text { dasi } \\
\text { Lajur }\end{array}$ & $\begin{array}{c}\text { Pon- } \\
\text { dasi } \\
\text { Bujur } \\
\text { sang- } \\
\text { kar }\end{array}$ & $\begin{array}{c}\text { Pondasi } \\
\text { Lingkar- } \\
\text { an }\end{array}$ & $\begin{array}{c}\text { Keterang- } \\
\text { an }\end{array}$ \\
\hline $\begin{array}{l}\text { Lem- } \\
\text { pung } \\
\text { lanauan }\end{array}$ & $\begin{array}{l}1,584- \\
13,620\end{array}$ & $\begin{array}{l}1,846- \\
17,179\end{array}$ & $\begin{array}{l}1,836- \\
17,124\end{array}$ & $\begin{array}{l}\text { Rendah - } \\
\text { Sedang }\end{array}$ \\
\hline $\begin{array}{l}\text { Lem- } \\
\text { pung } \\
\text { pasiran }\end{array}$ & $\begin{array}{c}5,347- \\
5,756\end{array}$ & $\begin{array}{c}6,535- \\
6,875\end{array}$ & $\begin{array}{c}6,495- \\
6,807\end{array}$ & Rendah \\
\hline $\begin{array}{l}\text { Tanah } \\
\text { lapu- } \\
\text { kan ba- } \\
\text { tupasir } \\
\text { tufan- } \\
\text { breksi }\end{array}$ & $\begin{array}{l}6,786- \\
13,020\end{array}$ & $\begin{array}{l}8,217- \\
16,196\end{array}$ & $\begin{array}{l}8,150- \\
16,112\end{array}$ & $\begin{array}{l}\text { Rendah - } \\
\text { Sedang }\end{array}$ \\
\hline
\end{tabular}

\section{Daya Dukung Pondasi Dalam}

Pondasi dalam pada kasus ini merupakan jenis pondasi dengan kedalaman pondasi lebih besar dari dua kali lebar pondasi (D>2B). Perhitungan besarnya daya dukung untuk pondasi dalam dengan tiang pancang tunggal mempergunakan pendekatan dari data sondir.

Persamaan yang digunakan untuk menghitung besarnya pondasi tiang pancang tunggal adalah rumus Begemann (1965) yaitu:

$$
\begin{gathered}
Q_{\text {ult }}=q_{c} x A_{p}+J H P x A_{s} \\
Q_{\text {all }}=\left(\frac{q_{c}}{3}\right) x A_{p}+\left(\frac{J H P}{5}\right) x A_{s}
\end{gathered}
$$

Dimana :

$\mathrm{Q}_{\text {ult }}=$ Kapasitas Daya Dukung Ultimit Pondasi

Tiang Tunggal, ton

$\mathrm{Q}_{\text {all }}=$ Kapasitas Daya Dukung Ijin Pondasi
Tiang Tunggal), ton

$\mathrm{q}_{\mathrm{c}}=$ Tekanan Konus, $\mathrm{kg} / \mathrm{cm}^{2}$

$\mathrm{JHP}=$ Jumlah Hambatan Pelekat, $\mathrm{kg} / \mathrm{cm}$

$\mathrm{A}_{\mathrm{p}}=$ Luas Penampang Tiang, $\mathrm{cm}^{2}$

$\mathrm{A}^{\mathrm{p}}=$ Keliling Selimut Siang, $\mathrm{cm}$

Asumsi yang digunakan adalah diameter tiang $30,00 \mathrm{~cm}$.

Kapasitas daya dukung ultimit tiang pancang tunggal pada kedalaman 5,00 m berkisar antara 17,218 - 54,464 ton sedangkan kapasitas daya dukung ijin tiang 4,126 - 13,064 ton (Tabel 6), sedangkan pada kedalaman $10,00 \mathrm{~m}$, daya dukung ultimit berkisar antara 49,714 - 134,230 ton dan daya dukung ijin tiang 11,182 - 36,164 ton (Tabel 4.4).

Tabel 6 Daya Dukung Pondasi Tiang Pancang

\begin{tabular}{|c|c|c|c|c|}
\hline \multirow{2}{*}{$\begin{array}{c}\text { No } \\
\text { Sondir }\end{array}$} & $\mathbf{q c}$ & JHP & $\mathbf{Q}_{\text {ult }}$ & $\mathbf{Q}_{\text {all }}$ \\
\hline & $\begin{array}{l}(\mathrm{kg} / \\
\left.\mathrm{cm}^{2}\right)\end{array}$ & $(\mathrm{kg} / \mathrm{cm})$ & (ton) & (ton) \\
\hline S1 & 9,279 & 195,072 & 24,932 & 5,860 \\
\hline S2 & 23,046 & 240,755 & 38,961 & 9,963 \\
\hline S3 & 16,519 & 335,895 & 43,312 & 10,219 \\
\hline S4 & 11,829 & 207,410 & 27,895 & 6,693 \\
\hline S8 & 13,154 & 277,873 & 35,469 & 8,333 \\
\hline S9 & 7,240 & 128,484 & 17,218 & 4,126 \\
\hline S10 & 9,279 & 169,375 & 22,511 & 5,376 \\
\hline S11 & 13,154 & 199,762 & 28,111 & 6,861 \\
\hline S12 & 9,279 & 157,954 & 21,435 & 5,161 \\
\hline S13 & 9,891 & 164,582 & 22,492 & 5,430 \\
\hline S14 & 12,543 & 246,465 & 32,078 & 7,597 \\
\hline S15 & 9,279 & 272,162 & 32,194 & 7,313 \\
\hline S16 & 9,891 & 280,728 & 33,433 & 7,618 \\
\hline S17 & 13,868 & 239,735 & 32,381 & 7,783 \\
\hline S18 & 23,046 & 405,337 & 54,464 & 13,064 \\
\hline S19 & 13,154 & 205,473 & 28,649 & 6,969 \\
\hline S20 & 17,845 & 303,468 & 41,194 & 9,920 \\
\hline
\end{tabular}
Tunggal Kedalaman 5,00 m 
Tabel 7 Daya Dukung Pondasi Tiang Pancang Tunggal Kedalaman 10,00 m

\begin{tabular}{|l|c|c|c|c|}
\hline $\begin{array}{c}\text { No } \\
\text { Sondir }\end{array}$ & $\mathbf{q c}$ & $\mathbf{J H P}$ & $\mathbf{Q}_{\text {ult }}$ & $\mathbf{Q}_{\text {all }}$ \\
\cline { 2 - 5 } & $\begin{array}{c}\mathbf{k g} / \\
\mathbf{c m}^{2} \text { ) }\end{array}$ & $\begin{array}{c}\mathbf{( k g} / \\
\mathbf{c m} \text { ) }\end{array}$ & (ton) & (ton) \\
\hline S1 & 14,480 & 451,938 & 52,803 & 11,925 \\
\hline S2 & 24,371 & 720,226 & 85,064 & 19,308 \\
\hline S3 & 16,519 & 949,560 & 101,119 & 21,780 \\
\hline S4 & 16,519 & 665,059 & 74,320 & 16,420 \\
\hline S8 & 19,782 & 714,515 & 81,284 & 18,120 \\
\hline S9 & 98,912 & 351,088 & 102,954 & 29,908 \\
\hline S10 & 98,912 & 683,108 & 134,230 & 36,164 \\
\hline S11 & 15,194 & 546,160 & 62,183 & 13,868 \\
\hline S12 & 15,806 & 435,725 & 52,212 & 11,931 \\
\hline S13 & 11,829 & 517,608 & 57,116 & 12,537 \\
\hline S14 & 11,829 & 595,616 & 64,464 & 14,007 \\
\hline S15 & 13,154 & 640,382 & 69,618 & 15,163 \\
\hline S16 & 18,457 & 541,367 & 64,037 & 14,546 \\
\hline S17 & 19,171 & 564,209 & 66,693 & 15,144 \\
\hline S18 & 98,912 & 608,975 & 127,247 & 34,767 \\
\hline S19 & 20,496 & 511,898 & 62,701 & 14,471 \\
\hline S20 & 25,085 & 739,294 & 87,364 & 19,836 \\
\hline
\end{tabular}

\section{Kesimpulan}

Berdasarkan hasil analisis tanah di daerah penelitian dapat disimpulkan beberapa hal sebagai berikut:

1. Tanah bersifat tidak jenuh dan memiliki kemampuan menyerap air yang tinggi.

2. Potensi perubahan komposisi kandungan dalam rongga (air dan udara) cukup tinggi.

3. Nilai Qc menunjukkan daya dukung tanah termasuk dalam kategori rendah hingga sedang.

4. Daya dukung pondasi dangkal untuk berbagai jenis pondasi adalah:

a. Pondasi lajur bervariasi mulai dari 1,584 ton $/ \mathrm{m}^{2}$ hingga 13,620 ton $/ \mathrm{m}^{2}$.

b. Pondasi bujur sangkar 1,846 ton $/ \mathrm{m}^{2}$ hingga 17,179 ton $/ \mathrm{m}^{2}$.

c. Pondasi lingkaran berkisar antara 1,836 ton $/ \mathrm{m}^{2}$ hingga 17,124 ton $/ \mathrm{m}^{2}$.

5. Daya dukung pondasi tiang pancang tunggal untuk kedalaman 5,00 m berkisar antara 4,13 - 13,06 ton/tiang, sedangkan pada kedalaman 10,00 m berkisar antara 11,18 - 36,16 ton/tiang. 


\section{Daftar Pustaka}

Bambang, P. \& Arif, H., 2006, Pengaruh Kadar Air Optimum Dengan Variasi Kepadatan Terhadap Potensi Dan Tekanan Mengembang Pada Tanah Ekspansif, Media Komunikasi Teknik Sipil, vol. 14, No.2, Ed. XXXV, Undip.

Bagemann, H.K.S., 1965, The friction jacket gone as an aid in determining the soil profile, Proceeding of the 6th International Conference on Soil Mechanics and Foundation Engineering, ICSMFE, Montreal, vol 2.

Bemmelen. R. W., 1949, The Geology of Indonesia, v. I.A. Government Printing Office.

Fang, H.Y., and Daniels, J.L., 2006, Introductory geotechnical engineering : an environmental perspective, Taylor\&Francis, New York.

Howard, A.D., 1978, Geology in Environmental Planning, McGraw - Hill, USA

Hardiyatmo H.C. 2002, Mekanika Tanah I, Gramedia Pustaka Umum, Jakarta

SNI 2827:2008 tentang Cara Uji Penetrasi Lapangan dengan Alat Sondir

U. Hatono, Baharuddin dan K. Brata, 1992, Peta Geologi Lembar Madiun, Jawa Timur Skala 1: 100.000, PPPG, Bandung.

Wawan, H., dan Ediwan, A.S., 2010, Pemetaan Geologi Teknik Tinjau Lembar madiun Skala 1:100.000, Provinsi Jawa Timur, Badan Geologi, Bandung 